\title{
Education Policies for Gifted Children Within a Human Rights Paradigm: a Comparative Analysis
}

\author{
Ivona Ninkov ${ }^{1}$
}

Published online: 6 October 2020

(C) The Author(s) 2020

\begin{abstract}
Gifted students are the most important part of every society and keeping the gifted child challenged and engaged is necessary. This paper aims to offer suggestions for the appropriate education system to enlarge their knowledge and creativity, without disturbing their usual life and educational surroundings. The author uses a comparative method, focusing on different countries worldwide and comparing and interpreting the various concepts of education in those countries. Based on the United Nations regionalization, the author focuses on the countries of the Eastern European Group (Bosnia and Herzegovina, Croatia, Hungary, and Serbia) and Western European and Others Group (Austria, Germany, Netherlands, UK, Turkey, and the USA). The study finds that inclusive education as an alternative framework is potentially the best education system for gifted students. The prevailing opinion in most countries is that the concept of inclusive education primarily refers to children with special needs. This authorexplains that there is no logical obstacle to applying inclusive education to gifted students as well. Such an inclusive education system would require changing current education systems and programs and, most of all, hiring various professional staff as social workers and trained teachers who can meet the various demanding needs of gifted students in any community. The study concludes that it is necessary to improve existing policies in education to provide the inclusive education framework to gifted children and to understand that the essence is not only to agree on differences but to stimulate the individuality and diversity of the gifted at all levels; the greatest gem of each country is its educated children. Inclusion of gifted students has a positive outcome not only for the individual but also for the other students in the classroom. Gifted students stimulate the others, pushing them to reach their potential academic capabilities. Also, the unidentified students who could learn at elevated levels could benefit from this kind of education model and a high level of instruction could push them in the same way that it challenges the gifted students in the classroom.
\end{abstract}

Keywords Rights of the gifted $\cdot$ Inclusion $\cdot$ Legal systems $\cdot$ Education $\cdot$ Social work $\cdot$ Human rights

\section{Introduction}

Human rights are universal and inalienable, indivisible, interdependent, and interrelated. They are universal because everyone is born with and possesses the same rights, regardless of where they live, their gender or race, or their religious, cultural, or ethnic background. They are inalienable because people's rights can never be taken away. They are indivisible and interdependent because all rights - political, civil, social, cultural, and economic - are equally important and cannot be fully enjoyed without the others. They apply to all equally, and all have the

Ivona Ninkov

ivonakakas@yahoo.com

1 Doctoral School on Safety and Security Sciences, Obuda University, Budapest, Hungary right to participate in decisions that affect their lives. The rule of law upholds and strengthens them, through legitimate claims on duty-bearers for accountability to international standards.

One of the most important basic human rights is the right to education. This human right enables us to understand the world around us, explain different phenomena, and express our interests. To explain the syntagma "the right to education" as precisely as possible, we must look at different international treaties, such as Article 26 of the Universal Declaration on Human Rights (UDHR) (UN 1948) and Article 5 of the Convention against Discrimination in Education (UN 1960). The UDHR clearly and concisely explains that education should be free, compulsory, and available to all under equal conditions. Human rights are primarily universal moral norms that bind all people on the planet; consequently, we observe them through the prism of internationally recognized conventions that legally grant these rights (Gordon 2013). 
The other important convention in this context is the Convention on the Rights of the Child (CRC). It recognizes education as a legal right of every child consistent with equal opportunity. Article 28 guarantees free compulsory primary education for all; progressive free secondary education that should be available and accessible to all in any case; and accessibility to higher education within the bounds of capacity. It states the obligation of the State to take measures regarding school attendance and discipline. It encourages international cooperation in matters related to education, in particular, elimination of ignorance and illiteracy and access to scientific and technical knowledge. Article 29 defines the aims of education and recognizes also the liberty of parents to choose the kind of education they want to give to their children and establish and direct educational institutions, in conformity with minimum standards laid down by the State. According to CRC, education should focus on full personality development and strengthening respect for human rights and fundamental freedoms (UN 1989).

Each of these treaties proclaims that education should be available to all, under equal conditions. International human rights law has clearly established that not all distinctions in treatment constitute discrimination, summed up by the axiom "persons who are equal should be treated equally and those who are different should be treated differently." Hence, certain situations may justify different treatment, such as, for example, the treatment of the gifted. Although not all differences in treatment are discriminatory, international law establishes criteria for determining when a distinction amounts to discrimination. One of the first judgments at the international level that determines the scope of the principle of nondiscrimination was one the European Court handed down in the decision on the Belgian Linguistic case ("Relating to Certain Aspects of the Laws on the Use of Languages in Education in Belgium," Application Nos. 1474/62, 1677/62, 1691/62, 1769/63, 1994/63, 2126/64, Judgements of 23 July 1968). In this judgment, the European Court agreed that not all types of differential treatment in the provision of rights and freedoms constitute prohibited discrimination under the Convention. In this judgment, the Court set forth its analytical scheme for determining when prohibited discrimination has occurred.

In the widest sense, the principles of education rest on the idea that children should receive all resources necessary to fulfill their dreams (Hodges et al. 2018). Applying the logical interpretation to gifted students, education should meet numerous and various needs these students usually have. Such a concept underpins inclusive education.

Different theoretical perceptions and doubts exist as to the term "giftedness" and the concept itself. Giftedness as a construct is problematic because it is likely neither static nor dichotomic. Terman, one of the pioneers in this field, considers students in the "gifted" category those who rank within the top $1 \%$ on standard intelligence tests. This interpretation started to fall out of favor during the mid-twentieth century when it was believed that standardized tests should not subordinate the determination of intelligence as a kind of guideline for revealing the degree of giftedness. Furthermore, the Marland report (1972) defined gifted children as those who perform well using general mental ability and have excellent special abilities in a certain academic field, creative and productive thinking, leadership ability, talent in visual performing arts, and/or psychomotor ability. Woods (2016) defines gifted and talented children as those distinguished from their peers by their general and/or special abilities. Gifted children are rare, while the adults' ability to perceive giftedness is often quite limited (Kelemen 2012). In most cases, recognizing gifted children is difficult (Pfeiffer 2002). Even when they are perceived as such, parents and teachers often do not know how to develop and improve the child's innate giftedness in the best possible way. More importantly, giftedness and talent are not static categories, but rather continuous processes resulting from the interaction of different factors, such as individual predispositions, one's ability to influence his/her own development, and the influence of upbringing (Ozcan and Gunduz 2016). Making the identification of "gifted" can occur through assessment, the "differential, individualized and accurate identification and evaluation of problems, people and situations and of their interrelations, to serve as a sound basis for differential helping interventions" (Siporin 1975).

Reynolds and Kaiser (1990) conclude that little or no evidence substantiates any claim of bias in most well-constructed tests of intelligence. They report that in well-prepared standardized tests, content bias was a very irregular occurrence. Expert judges (minority or nonminority) could ascertain no common characteristics of items biased against certain groups. From a review of studies of construct validity, involving a variety of populations of minority and white children of different races and genders, and investigations that used a large number of popular psychometric assessment instruments and multiplicity of methodologies, Reynolds and Kaiser (1990) conclude that no consistent evidence of bias in construct validity exists in any of the many tests investigated.

At first glance, recognizing giftedness in the fields of art, music, and sports is quite easy (Blaquer 2011). These categories enjoy the benefits of sports classes and arts and music schools that organize such classes. The alarming issue is that other gifted children, who do not demonstrate these clearly visible talents, require an active and planned strategy for the emergence of their particular gifts. Often, educational support for gifted children is neglected due to inertia, since these children already differ from their peers and additional stimulus is not necessary. Giftedness implies a higher degree of individual achievements in specific areas than the child's peers show. 
Thus, it is necessary to provide gifted children with full support up to the maximum when developing their capacities. The reason for this is that a tremendous advantage over others can easily become a disadvantage, especially if the gifted children are not directed in the right way.

Guided by the education systems for the gifted students and exploring the concept of inclusive education in different countries (mainly applied for the children with special needs), this study aims to offer the new concept of inclusive education of gifted students, providing them with full and consistent support to the maximum while developing their capacities. The author thinks that the term "human need" is very close to the paradigm of human rights and, as one of the objects of human rights protection, the right to education that considers the gifted ones as well. Developing a strategy for identifying high-ability students and those with special talents requires engaging a variety of professional staff, such as teachers, parents, doctors, and social workers. For this reason, the author believes that social workers are an indispensable link in identifying gifted students. The fundamental mission of the social-work profession is to serve adults or children needing assistance and to make social institutions more responsive to human needs.

The paper consists of five parts. After defining the term "gifted children," it presents an overview and comparison of legal acts regulating the rights of gifted students within various legal systems. It interprets concepts of inclusive education in different countries and compares concepts of inclusion. Finally, it presents findings and suggests conclusions about inclusive education for gifted children.

\section{Methodology and Comparison of Legal Regulations}

Every country has its educational policy and legal regulations concerning gifted children. This section applies the comparative method, focusing on different countries. Similarities and differences observed through various education systems provide a basis for forming an opinion on the legal aspects of inclusive education for gifted children.

The United Nations regionalization divides the world's countries into five regional groups (UN 2019): The African Group, the Asia-Pacific Group, the Latin American and Caribbean Group, the Eastern European Group, and the Western European and Others Group (WEOG). Our research considers countries from the last two European groups: four countries of the Eastern European Group (Bosnia and Herzegovina, Croatia, Hungary, and Serbia) and six countries of the WEOG (Austria, Germany, the Netherlands, UK, Turkey, and the USA).

\section{Legal Regulation in Eastern European Group Countries}

The Framework Law on Primary and Secondary Education in Bosnia and Herzegovina (PSBiH 2003) has guidelines for the education of children with special needs but does not recognize gifted students as a special category. Article 4 of the Framework Law on Primary and Secondary Education of Bosnia and Herzegovina stipulates that every child has the same right and equal opportunity to access an appropriate education without any discrimination.

The Primary and Secondary School Education Act in the Republic of Croatia (NN 2017) recognizes the category of gifted students, instructing schools to monitor and encourage these students through additional assignments, according to their preferences, abilities, and interests, as the Ministry of Education more precisely defines them. Basic arts schools have a special position in gifted education, with many music schools in the country. Special classes in elementary and secondary schools and the regionally based sports schools cater to those with talents in sport. The existence of special colleges, whose activities facilitate equal rights in education, also advance high levels of ability. The extracurricular activities occur once a week and last one-to-two hours.

Looking at the Hungarian educational system, we see that gifted students receive excellent treatment and quite a good starting point from which to develop their talents even further. The selection and identification of gifted students are based on several criteria: within-school and external achievement (e.g., winner of a competition) and teacher and expert nominations, mainly psychologists. This system recognizes gifted students as those who require special treatment (Reid and Boettger 2015 , p.164). Since the late 1980s, the schools have implemented the so-called complex developmental programs that focus not only on skills and abilities development but also on the personal background of the individual. What particularly stands out in the Hungarian Education Law (2011. Evi CXC 2018) is the application of "enriched" teaching, comprising additional classes, custom assignments, and various external competitions, while skipping classes or sharing classes with older students is a rarity. Increasingly, more teachers take part in daily training programs in gifted education, with the ultimate goal of training one teacher per school who specializes in gifted students to coordinate the work and progress of these students (Monks and Pfluger 2005).

According to the Law on the Foundations of the Education and Upbringing System of the Republic of Serbia (OGRS 2017), the preschool, primary, and secondary education systems framework, along with adult education, pay special attention to work with gifted children. Thus, Article 3 of the law claims that persons with exceptional abilities have the right to special education responsive to their upbringing and special educational needs, in terms of special classes or special 
schools. Furthermore, Article 56 provides the possibility of organizing individual programs for exceptional students at both the elementary and secondary levels of education. In addition, according to the Law on the Basis of the System of Education and Training, the educational institution can adapt the school program to students who achieve outstanding results in the field of education, which includes adopting an individual educational plan. This plan is a special act to satisfy the educational needs of the child or student. The pedagogical collegium of the institution endorses it, including the suggestion for inclusive education, i.e., the team for providing the additional support to the students, consisting of a teacher, a professional associate, an associate, and a parent or other legal representative. According to Article 76 of the Individual Educational Plan (IPO 3 2017), the deepening and expanding content of educational activities of children with exceptional abilities is the aim.

\section{Legal Regulation in WEOG Countries}

Even though Western European countries are said to have advanced the approach in several fields, such as economy and social policy, we conclude that this is not the case in educational models in every country. For example, the education system in the Netherlands relies on the concept of a "broad middle group" with no clear student selection - on the one hand, very "weak," less capable, or struggling and, on the other hand, gifted, highly advanced, or excellent students. Also, this comes from the national creed (Greet et al. 2013, p. 134) "Do not stand out" and "Good is good enough." The Dutch culture is negatively criticized as a culture of C's, with no place for top universities, pioneering research, or leading companies such as Apple, and as a rather egalitarian country with no place for those who stand out. However, according to Greet et al. (2013, p.135), in a situation where students are not separated according to their ability level and teachers themselves were not "gifted students" in their early education process, a mismatch occurs. If a group of students is gifted and superior to average teachers in intelligence, ways of thinking, or metacognitive skills, a misalignment between students and teachers occurs. The Ministry of Education, Culture, and Science of the Netherlands went the extra mile, overcoming the inclusion of gifted students and possibly gravitating toward positive discrimination through a manner of segregation. To illustrate, the Ministry developed plans and measures and founded schools with a gifted educational profile and plan, as well as schools with the Leonardo concept (school-within-a-school).

A remarkable improvement in the treatment of gifted children is clearly visible in Germany. According to Basic Law 1949, schools have two educational models: "accelerated learning," which requires a high level of ability in quick data processing, and "enrichment" (extensive learning), which requires a high level of ability in huge amounts of data processing (Fischer and Müller 2014). In addition, outside the school system, different associations and foundations for gifted students exist, representing the new wave of reorganizations of inclusive education. Some of the most important associations are the Bildung \& Begabund and parents' associations, as primary observers of gifted children. Other such associations are Deutsche Gesellschaft für das hochbegabte Kind (German Association for Gifted Children), Hochbegabtenförderung e.V (Society for Gifted Education), and "Mind - Mensa in Deutschland e.V" (Mensa in Germany). Some of the most famous foundations in Germany are the Karg-Stiftung für Hochbegabtenförderung - Karg (Foundation for Gifted Education) and the Stifterverband für die Deutsche Wissenschaft (Association of Foundations for Science in Germany). Also, there is the German Government Foundation (Deutschlandstipendium), as well as the Foundations of the Catholic (Cusanuswerk) and the Protestant Church (Evangelisches Studienwerk Villigst). One of the most important foundations is the "Deutsches Schülerstipendium" (German Student Scholarship), which supports highly capable students from poor families. All of this gives a conceptual model that different countries could adopt, beyond the government's framework of measures and action plans.

Keeping in mind that gifted children represent the largest source of the country's immaterial wealth (Omeroglu et al. 2017) and the basis of future development and shaping the future of the state, in Turkey, an assembly called Grand National Assembly of Turkey (TGNA) is a working group focused on improving the status of gifted children, who receive adequate and timely support during their education.

Further, in Austria, when the Education Act passed in 1962, it explicitly mentioned that the gifted should receive adequate protection (Reid and Boettger 2015). In 1970, the practice was introduced for students who exhibited talent to possibly skip a grade. In 1990, the gifted were recognized as the special category, with all rights that belonged to children with learning difficulties or disabilities. In 1999, a special Austrian Center for Research and Support for the Gifted and Talented was established to support both gifted children and their parents and teachers. The school legislation of Austria emphasizes a general idea of individualized education and autonomous creation of the individual school career, through acceleration and enrichment within the regular school, as well as within specific schools. The identification of gifted students lies mainly in the hands of experts such as school psychologists, teachers, or scientists, who use standardized tests. Information that parents provide is also significant and welcome.

In the USA, we find the extraordinary situation of gifted students and their education nurtured since the 1920s and 1930s (Kincheloe and Weil 2001). The pioneers in this field, including Terman and Hollingworth, expanded this 
movement and conducted the first widely publicized research on gifted children. According to the National Association for Gifted Children (NAGC 2015), during the 1970s the movement received support in the form of statutory regulations when the federal government dealt with gifted issues specifically and introduced the National Standards in Gifted and Talented Education (NSGTE 2013). An extremely important legal act in this field is the so-called Javits' law (Civic Impulse 2018), named after Senator Jacob Javits for his role in promoting gifted education. The original 1988 law was revised in 1994 to create the opportunity for primary and secondary schools to meet the educational needs of gifted and talented students. Another very important legal act is the No Child Left Behind Act (USC 2002), which requires state schools financed from the federal budget to implement yearly standardized knowledge and skills tests among all students. This equalizes the initial possibilities of gifted students from middle and upper-class families and students from lower-income families. The legal regulation that replaced the "No Child Left Behind" Act is the "Every Student Succeeds Act" (ESSA), which came into force in 2015 (PUBLO 95 PS 2015). ESSA specifically notes that districts may use various funds to identify and serve gifted and talented students through various activities. These may include training to support the identification of gifted and talented students, including high-ability students who have not been formally identified for gifted education services, and implementing instructional practices that support the education of such students, including early entrance to kindergarten, enrichment, acceleration, and curriculum-compacting activities and dual or concurrent enrollment programs in secondary school and postsecondary education.
The UK went above and beyond when its government published a national strategy and standards to improve the education of gifted and talented children in schools. The Institution Quality Standard (IQS) is set up to make it easier for schools to plan gifted education, while the Classroom Quality Standard (CQS) is designed. Moreover, the Department for Children, Schools, and Families in the UK (DCSF 2008) has implemented a series of measures that aims to support gifted education, including the National Program for Gifted and Talented Education (2008), clearly defining that the program encompasses children and young people with one or more abilities developed far beyond their average age group.

Table 1 presents a comparative analysis of education policies and programs for gifted students in 10 selected countries from the Eastern European Group and WEOG.

Although the systems, policies, and education types and programs vary from country to country, most countries recognize the problem of educating gifted children and educate their gifted students in special schools and special classes in the school or outside of schools. Thus, numerous gifted students who cannot attend these institutions or do not wish to leave their homes are not educated properly.

\section{Discussion}

Comparing the legal instruments in the UK and the US systems makes evident that they are very similar. Gifted students are financially supported and part of special groups of students learning specially tailored programs; still, the USA provides

Table 1 Comparative analysis of education policies and programs for gifted students

\begin{tabular}{|c|c|c|}
\hline Country & Legal documents treating education of gifted students & Type of education programs of gifted students \\
\hline \multicolumn{3}{|c|}{ Eastern European Group } \\
\hline $\begin{array}{l}\text { Bosnia and } \\
\text { Herzegovina }\end{array}$ & Law on Primary and Secondary Education, 2003 & Programs for gifted students not recognized \\
\hline Croatia & Primary and Secondary School Education Act, 2017 & Special classes, Special schools, Individual programs for gifted \\
\hline Hungary & Hungarian Education Law, 2011 & Individual work \\
\hline Serbia & OGRS 2017 & Special classes, Special schools \\
\hline \multicolumn{3}{|l|}{ WEOG } \\
\hline Austria & The Education Act, 1962 & Individual study programs for gifted \\
\hline Germany & The Basic Law, 1949 & $\begin{array}{l}\text { "Accelerated learning" } \\
\text { Education for gifted outside schools }\end{array}$ \\
\hline The Netherlands & Primary Education Act, 1988 & Schools with the Leonardo concept \\
\hline Turkey & $\begin{array}{l}\text { Education Programs for Talented Students (EPTS), } \\
2007\end{array}$ & $\begin{array}{l}\text { Without special education system but strong financial support to } \\
\text { gifted }\end{array}$ \\
\hline UK & $\begin{array}{l}\text { National Program for Gifted and Talented Education, } \\
2008\end{array}$ & Various study programs for gifted students \\
\hline USA & Every Student Succeeds Act, 2015 & Strong financial support for gifted and talented \\
\hline
\end{tabular}


the most financial support for educating gifted students. However, neither the UK nor the USA has an inclusive education program. In the UK, even if the legislation does not explicitly mention giftedness or gifted education, a variety of published legislative regulations and guidelines for gifted education exists. The current UK government came to power in 2015 on a platform of "Education Education Education." This led to an increased profile of the needs of Able, Gifted, and Talented Pupils and the publication of various policy documents, statements of intent, and working papers. In 1999, the "Office for Standards in Education International Research Survey" was published. A national "Gifted and Talented Advisory Group" was established. The Select Committee inquiry shaped the agenda of the "Gifted and Talented" strand of Excellence in Cities and was the precursor of a national strategy to support individual LEAs and schools in developing their provision for able pupils. The revised National Curriculum "access" and "inclusion" statements (Department for Education and Employment/Qualification Curriculum and Assessment 1999) make it a statutory responsibility to "provide for all pupils" according to their abilities. The most common nomination procedures are teacher nominations, including nomination based on school achievement and outside of school achievement. Also, peer-nomination, parent-nomination, and self-nomination occur.

The other countries mentioned above have much greater differences. For example, in Bosnia and Herzegovina, the gifted children are not recognized as a special group of students, while in Croatia, these students are specially treated and regulation is delegated to the Ministry of Education. Similarly, in Austria, the Research Center for Gifted Students is established.

The Netherlands was the first to introduce the concept of "school-within-a-school" for gifted students. Special classes for gifted children were organized. Unfortunately, the idea collapsed, due to an insufficient number of students as well as teachers. Although the idea was fantastic, it had different outcomes in practice. Often, a lack of challenging teaching materials for gifted students existed, while students with special needs received disproportionately more attention than gifted ones (Greet et al. 2013). The government of the Netherlands, together with numerous scientific institutions, carried out a series of projects from 2000 to 2010 to clearly define the talents of gifted students, defining the gifted student as someone with a natural ability that needs development, directly depending on an exceptionally stimulating environment (de Boer et al. 2013). The nonprofit organization "Vierkant voor Wiskunde" organizes provisions for students interested and gifted in mathematics. Some schools offer extracurricular activities, mainly in sports and music. A few special schools emphasize sports and music. These schools normally cooperate with special institutes in sports and music to ensure adequate provisions for students. This format has been extended in the so-called bagaafdheidsprofielscholen, schools that offer special counseling for academically gifted students, just as other schools provide services in the areas of sport and music. Identification criteria for giftedness are not explicitly determined; schools, institutes, and organizations that offer provisions generally define their own criteria.

In Germany, some associations and foundations outside the schools are founded to deal with gifted students, financially supported but having nothing to do with the education in the official school system. In Turkey, however, a working group advances the gifted ones with adequate protections.

Hungary and Serbia developed very similar legal approaches for gifted students, with individual programs and educational plans intended. Unfortunately, financial support is minimal.

We must comprehend that no clear legal guidelines, measures, and action plans exist for the education of gifted students. Each country individually finds suitable measures and a manner of enabling the development and empowerment of gifted children.

While researching the previously mentioned educational systems in various countries, we found that, in general, they require special schools or classes for gifted students. The number of these schools in a country is financially limited and limited by the number of highly educated teachers for these students. The problem is finding professional staff and financial support.

Having researched various educational systems in different countries, the author concluded that the programs for gifted students are very limited among schools and require some better approach to settle the financial, social, and educational aspects of the gifted ones. The author finds that the inclusion of an alternative framework should be introduced.

\section{Inclusive Education: Findings}

As the introduction mentions, the Convention on the Rights of the Child (CRC 1989) recognizes education as a legal right of every child on the basis of equal opportunities, the basic guidance of the inclusion framework. This is presented in Article 28 and confirmed in Article 29, giving parents the liberty to choose the kind of education they want to give to their children.

CRC is the most widely ratified human rights convention (ratified by 194 countries, including every member of the United Nations except the USA), which deals with the childspecific needs and rights. Article 29 of the Convention leaves open the possibility that inclusive education as a concept can be applied to the category of gifted ones.

Inclusive education means different and diverse students, learning side by side in the same classroom while they all enjoy field trips and after-school activities together. 
Inclusive education values diversity and unique contributions that each student brings to the classroom. It represents an approach that looks into how to transform education systems in order to respond to the diversity of learners. Gifted children should be able to benefit from appropriate educational conditions, and with the simple analogy, the author thinks no obstacle to applying the inclusive-education concept to the gifted ones should exist. Appropriate educational conditions should allow them to fully develop their abilities, for their own benefit and that of their society. Indeed, no country can afford to waste talents, and not to identify any intellectual or other potentialities would be a waste of human resources. Of course, children must not be treated as potential saviors of the nation, but the appropriate education for the gifted ones must be the priority. In a basic sense, inclusive education refers to children with special needs. However, the author does not find any obstacle to applying inclusive education for gifted ones, because the root for both categories is equal - a tailored education. If the gifted category cannot be included in the concept of inclusive education, gifted children cannot enjoy the benefits of inclusive education, such as special programs, qualified teachers, adapted work-materials, tailored materials, and financial support. Gifted education is often an afterthought for many schools whose focus is on general students' proficiency, and not much money is allocated for gifted programs. As a result, many gifted programs run on a very small budget and have limited resources. Inclusive programs could resolve these financial problems, as these programs are financially stable and supported.

Above all, the positive outcome for the classrooms with gifted children in them could be the stimulation of the others. Gifted ones could stimulate the others, pushing them to realize their academic capabilities. Children are more likely to reach their potential when challenged academically. Also, many non-identified students in heterogeneous classrooms can learn at elevated levels and a high level of instruction that pushes them in the same way it challenges the gifted students in the classrooms.

Different countries take various approaches to the concept of inclusion and inclusive education. In the USA, inclusion is defined as providing services to students with disabilities, including those with severe disabilities, to ensure a child's social adaptation (Frederickson and Cline 2002, p. 66). Moreover, in the UK, different organizations and institutions have created several definitions and grounds. To illustrate, the Ministry of Education states in its official document "Inclusive Education" that schools that a local education authority supports should actively seek to remove barriers to learning and participation that can hinder or exclude learners with special needs (DfES 2001, par. 7). The Center for Studies on Inclusive Education (CSIE), an organization promoting the growth of inclusive schools in the UK, sees that inclusion enables all students to fully participate in life and work, regardless of their needs; it is also a permanent process for removing the barriers to learning and participation for all children and young people. The Equity Group Association from Scotland believes that inclusive education recognizes that children have equal rights and equal value. This should be a fundamental starting point for education and social policy in modern society.

Interestingly, the concept of inclusive education in Turkey, as the Rulebook on Special Education of the Ministry of Education establishes it, implies that inclusive education is a special educational practice based on the principle that the education of individuals with special needs continues with peers without disabilities in state and private schools, preschool, elementary school, and adult education, providing them with educational support services (Melekoglu et al. 2009). Finally, in the Netherlands, inclusive education is called "the appropriate education" (Thijs et al. 2016).

Regarding the rights of the gifted, addressing the very current topic of inclusive education is necessary, referring not only to the education of children with disabilities as inclusion in the regular educational system but also to quality education for all children. Every democratic society first must emphasize tolerance as a basis for respecting diversity, to enable implementing and accepting inclusive practice (Velišek 2013).

According to my research, inclusion is best defined as a process. Regardless of diversity, the inclusion of every child in the educational system should develop in parallel with social inclusion. Observing the concept of inclusive education proceeds from linguistic and logical interpretation as a widespectrum concept, without any obstacles that gifted students may encounter. If inclusive classrooms are planned for all students, this kind of education must apply analogously to the most extreme examples of gifted students, as well as to those with the most severe shortcomings and difficulties (Kearney 1996). The very concept of inclusive education implies an education system tailored to a child in accordance with his or her needs. Frequently, inclusive education is associated with students with developmental disabilities, and the adaptation of educational programs refers to this student category. Some authors, such as Gordon and other opponents of "full-inclusion," argue that not all children with developmental disabilities can be part of an inclusive education system. He points out that it is completely unreasonable to expect, for example, deaf students to participate in classes and share classrooms with pupils who do not have this disability. Also, it is unrealistic for inclusive education to be compulsory if parents estimate that a special mode of education will be of greater benefit to this vulnerable group of children (Gordon 2013). Accordingly, it is important to invoke the Law on the Prohibition of Discrimination (SGRS 2009), which implies direct and indirect discrimination. According to Article 6, direct discrimination exists if, due to personal characteristics, a 
person or a group of persons in the same or similar situation is or could be placed in a more unfavorable position. Article 7 states that indirect discrimination exists when a person or a group of persons is placed in an unfavorable position by an act, action, or omission that is apparently based on the principle of equality and nondiscrimination unless justified by a legitimate goal, while the means to achieve that goal are appropriate and necessary.

Invoking the provisions of this law leads to the conclusion that gifted students do not appear to be placed in an unequal position, compared with other students. Opening the door to inclusive education implies that children should have access to regular education, while the teaching staff must adapt their mode of teaching to the individual needs of children. Inclusion means providing support to both employees and students, while the product of it all is a community that encourages and respects their differences (Booth and Ainscoll 2002). The most important immediate benefits of the inclusive educational framework for gifted students could be financial. If the school could benefit from financial aid for an inclusive framework, it could adapt its programs to various categories, the gifted as well. For example, providing enrichment/ extension activities, projects, greater use of IT possibilities, and extra-studies materials could achieve this. The biggest challenge could be the adequate education and training for teachers, to enable them to provide students with the best possible tailored programs.

While the education of the gifted, as well as their general status in the education system, is one of many burning issues, school social workers play a vital role while collaborating with teachers, parents, and administrators to provide optimal support for students. The role of social workers in schools is becoming essential, especially in terms of inclusion of marginalized children, by impacting the educational system to meet the diverse needs of all learners, the essence of inclusive education programs. Social workers collaborate with teachers and parents while identifying students with both special needs and giftedness. Further, they provide school staff with training programs on making schools and classrooms effective for diverse students. Also, they support teachers in drafting Individual Education Plans. Lynn et al. (2003) suggest that school social workers could emphasize home visits and dialogue with parents on how to carry over and modify school action plans for home use. They represent the bridge that brings together families, schools, and social services, to promote and support students' academic and social success. Also, they do direct counseling with individuals and families.

Social workers recognize the global interconnections of oppression and are knowledgeable about theories of justice and strategies to promote human and civil rights. Social work incorporates social-justice practices in organizations, institutions, schools, and society, to ensure that these basic human rights are distributed equitably and without prejudice (CSWE
2012, p5). An inclusive system benefits all learners without discrimination toward any individual or group. It is founded on values of democracy, tolerance, and respect for differences.

As champions of social justice, social workers understand the importance of helping vulnerable populations that face social, economic, political, and educational inequalities. Social workers, applying a social-systems theory (Hutchison 2011), analyze these inequalities within the context of the environments in which disadvantaged populations live and, then, advocate on their behalf. Although social workers have served a variety of populations (Gitterman 2014), the population of gifted students has received little attention, despite clear evidence that our educational institutions have not served many gifted students well.

\section{Conclusion}

Based on extensive research and all aforementioned evidence, we conclude that inclusive education enables the development and empowerment of gifted children, in accordance with their specific abilities, talents, and needs. Every country should accept the concept of inclusive education as applicable to gifted students as well. If the gifted category is not included in the concept of inclusive education, gifted children could not enjoy the benefits of inclusive education, such as special programs, qualified teachers, adapted work-materials, tailored materials, and financial support. Gifted education is often an afterthought for many schools, as their focus is on general students' proficiency, and not much money is allocated for gifted programs. As a result, many gifted programs run on a very small budget and limited resources. Financially stable and supported inclusive programs could resolve these financial problems. The social aspect of suggesting inclusive education is very important; the social advantages of this kind of program include one of the positive classroom outcomes of having gifted children in them for the stimulation of other students. They could push the others to reach their academic capabilities as children are more likely to reach their potentials when challenged academically.

Inclusive education is a relevant social-work goal because school social workers play a vital role while collaborating with teachers, parents, and administrators to provide optimal support for students. The role of social workers in schools is becoming essential, by impacting the educational system to meet the diverse needs of all learners, the essence of inclusive education programs. Social workers collaborate with teachers and parents while identifying students with special needs as well as giftedness. It is of vital interest to extend the inclusive model to all children, not just apply it for children with special needs.

Acceptance of this premise on both the theoretical and practical level and without any exception requires improving 
existing policies in education, with the aim of providing inclusive education to gifted children and understanding that the essence is not only to agree on differences but to stimulate the individuality and diversity of the gifted at all levels, because the greatest gem of each country is, truly, its educated children. Success in education for all children consistent with their possibilities should not be a utopia but an attainable goal in every country. Advancement in the area of gifted education is always dependent on input from policy makers, practitioners, scientists, teachers, and, of course, parents. Progress only occurs if mutual understanding and cooperation exist among these groups. The dynamic growth of gifted education since the beginning of the twenty-first century gives hope that this century is on the right track to becoming the century of the gifted child.

Funding Open access funding provided by Óbuda University.

\section{Compliance with Ethical Standards}

Conflict of Interest The author declares that there are no conflicts of interest.

Open Access This article is licensed under a Creative Commons Attribution 4.0 International License, which permits use, sharing, adaptation, distribution and reproduction in any medium or format, as long as you give appropriate credit to the original author(s) and the source, provide a link to the Creative Commons licence, and indicate if changes were made. The images or other third party material in this article are included in the article's Creative Commons licence, unless indicated otherwise in a credit line to the material. If material is not included in the article's Creative Commons licence and your intended use is not permitted by statutory regulation or exceeds the permitted use, you will need to obtain permission directly from the copyright holder. To view a copy of this licence, visit http://creativecommons.org/licenses/by/4.0/.

\section{References}

Blaquer. J. (2011). Activites sportives et educatives, Bulletin officiele, 38. Retrieved from http://www.education.gouv.fr/pid25535/bulletin officiel.html?cid_bo=57926.

Booth, T., \& Ainscow, M. (2002). Index for inclusion: developing learning and participation in schools. Bristol: Centre for Studies on Inclusive Education.

Civic Impulse. (2018). Jacob K. Javits Gifted and Talented Children and Youth Education Act of 1987.

CRC. (1989). Convention on the rights of child, OHCHR, Resolution 44/ 25 of 20 November 1989.

DCSF. (2008). Effective provision for gifted and talented children in primary education. Published by the Department for Children, Schools and Families, UK, 1-40, ISBN 978-1-84775-2.

de Boer, G., Minnaert, A. E., \& Kamphof, G. (2013). Gifted education in the Netherlands. Journal for the Education of the Gifted, 36(1), 133150. https://doi.org/10.1177/0162353212471622.

DfES. (2001). Inclusive schooling: children with special educational needs. Department for Education and Skills (DfES/0774/2001). 164 ISBN 184185629 0, London.
Evi, C. X. C. (2018). Torveny a nemzeti koznevelesrol, Wolters Kluwer, 30 june 2018, Retrieved from https://net.jogtar.hu/jogszabaly? docid=A1100190.TV.

Fischer, C., \& Müller, K. (2014). Gifted education and talent support in Germany. CEPS Journal, 3(4), 31-54.

Frederickson, N., \& Cline, T. (2002). Special educational needs, inclusion. Buckingham: Open University Press ISBN 033520973 $4(\mathrm{hb})$.

Gitterman, A. (Ed.). (2014). Handbook of social work practice with vulnerable and resilient populations. New York: Columbia University Press.

Gordon, J. (2013). Is inclusive education a human right? The Journal of Law, Medicine \& Ethics, 41(4), 754-767. https://doi.org/10.1111/ jlme.12087.

Hodges, J., Tay, J., Maeda, Y. \&, Gentry M. (2018). A meta-analysis of gifted and talented identification practices. Gifted Child Quarterly, 62(2), 147-174. doi: https://doi.org/10.1177/0016986217752107.

IPO 3. (2017). Pokrajinski zaštitnik građana Ombudsman, Podrška učenicima sa izuzetnim sposobnostima u osnovnim i srednjim školama u AP Vojvodini, 1-53, decembar 2017, Retrieved from www.ombudsmanapv.org/riv/attachments/article/1974/ DAROVITI-ucenici-istrazivanje-2017.pdf.

Kearney, K. (1996). Highly gifted children in full inclusion classrooms. Highly Gifted Children, 12(4), 1-11 retrieved from https://files.eric. ed.gov/fulltext/ED425575.pdf.

Kelemen, G. (2012). Identification of highly gifted children. Exedra, 6, $43-55$.

Kincheloe J. L., \& Weil, D. (2001). Standards and schooling in the United States, an encyclopedia.

Lynn, C. J., Kay, M. M. M., \& Atkins, M. (2003). School social work: meeting the mental health needs of students through collaboration with teachers. Children \& Schools.

Marland, S. P. (1972). Education of the gifted and talented. Report to the Congress by the U.S. Commissioner of Education. Washington, DC: U.S. Government Printing Office.

Melekoglu, M., Cakiroglu, O., \& Malmgren, K. (2009). Special education in Turkey. International Journal of Incluisive Education, 13(3), 287-298. https://doi.org/10.1080/13603110701747769.

Monks, F. J., \& Pfluger, R. (2005). Gifted education in 21 European countries: inventory and perspective. Netherlands: Radboud University Nijmengen.

NAGC. (2015). A brief history of gifted and talented education, National Association for Gifted Children (NAGC), Washington. Retrieved from http:/www.nagc.org/resources-publications/resources/giftededucation-us/brief-history-gifted-and-talented-education.

NN. (2017). Law on education in elementary and secondary school in Croatia, Consolidated Text on Law NN 87/08, 86/09, 92/10, 105/10, 90/11, 5/12, 16/12, 86/12, 126/12, 94/13, 152/14, 07/17, 26 January, 2017.

NSGTE. (2013). National standards in gifted and talented education.

OGRS. (2017). Law on the foundations of the education and upbringing system. Official Gazette of the Republic of Serbia, No. 88/2017.

Omeroglu, E., Sarikaya, R., Daglioglu, H. E., Kilic Cakmak, E., Karatas, S., Arici Bulut, S., \& Basit, O. (2017). The terms used in gifted and talented education in Turkey, relevant legal framework and educational practices. International Journal of Early Childhood Special Education, 1-30. https://doi.org/10.20489/intjecse.329697.

Ozcan, D., \& Gunduz, N. (2016). Gifted education policies in different countries. PONTE International Scientific Researches Journal, 72(6). https://doi.org/10.21506/j.ponte.2016.6.15.

Pfeiffer, S. (2002). Identifying gifted and talented students: recurring issues and promising solutions. Journal of Applied School Psychology, 1(1), 31-50. https://doi.org/10.1300/J008v19n01_03.

PSBiH. (2003). Framework Law on Primary and Secondary Education in Bosnia and Herzegovina, PSBiH No. 59/03, 30 June, 2003. 
PUBLO 95 PS. (2015). Every Student Succeeds Act. Public Law 114-95Dec.10, 2015, 129 Stat. 1802-2192 https://www.congress.gov/bill/ 114th-congress/senate-bill/1177/text

Reid, E., \& Boettger, H. (2015). Gifted education in various countries of Europe. Slavonic Pedagogical Studies Journal, 4(2), 158-171. https://doi.org/10.18355/pg.2015.4.2.158-171.

Reynolds, C. R., \& Kaiser, S. M. (1990). Test bias in psychological assessment. In T. B. Gutkin \& C. R. Reynolds (Eds.), The handbook of school psychology (pp. 487-525). Oxford: John Wiley \& Sons.

SGRS. (2009). Zakon o zabrani diskriminacije, Službeni glasnik Republike Srbije, br. 22/2009 retrieved From https://wwwparagraf. rs/propisi_download/zakon_o_zabrani_diskriminacije.pdf.

Siporin, M. (1975). Introduction to social work practice. New York: Macmillan.

Thijs, A., van Leeuwen, B., \& Zandbergen, M. (2016). Inclusive education in the Netherlands. SLO, Enschede, AN 2.4624.165 Retrieved from http://www.goprince.eu/wp-content/uploads/2016/11/ INCLUSIVE-EDUCATION-IN-THE-NETHERLANDS.pdf.

UN. (1948). UN General Assembly, Universal Declaration of Human Rights, 10 December 1948.
UN. (1960). UN Educational, Scientific and Cultural Organization (UNESCO), Convention Against Discrimination in Education, 14 December 1960.

UN. (1989). UN General Assembly, Convention on the Rights of the Child, 20 November 1989, United Nations, Treaty Series.

UN. (2019). United Nations Regional Groups of Member States, Department for General Assembly and Conference Management, United Nations, n.d. Retrieved 5 March 2019. https://www.un.org/ depts/DGACM/RegionalGroups.shtml.

USC. (2002). No Child Left Behind Act of 2001, P.L. 107-110, 20 U.S.C. $\S 6319$.

Velišek, B. (2013). Konstruktivistički prikaz inkluzije, polazišta kvalitetnog obrazovanja. Krugovi detinjstva, 1, 17-25.

Woods, J. (2016). State and Federal Policy: Gifted and talented youth. Retrieved on November 2016, from https://www.ecs.org/wpcontent/uploads/State-and-Federal-Policy-for-Gifted-and-TalentedYouth.pdf.

Publisher's Note Springer Nature remains neutral with regard to jurisdictional claims in published maps and institutional affiliations. 